\title{
The Historiography of the Black Panther Party
}

\author{
JOE STREET
}

This article examines forty years of historical writing on the Black Panther Party (BPP), arguing that this historiography has now reached maturity. It evaluates key publications on the BPP, splitting the historiography into three periods. The first phase, the article asserts, was dominated by accounts written by participants and observers of the BPP in action. These offered insight into the personalities of the BPP leadership but included relatively little on other BPP members. They were supplemented by a collection of friendly academic studies, a number of which emphasized the role of the FBI in precipitating the BPP's decline. The article identifies the I994 publication of Hugh Pearson's biographical study of Huey P. Newton as the beginning of a second phase. Pearson's work, which built on a collection of accounts written by observers and right-wing writers during the first phase, precipitated an outpouring of new studies that opposed its conclusions. These works overwhelmingly focussed on individual BPP chapters and the experiences of the BPP rank and file; they were generally friendly towards the party and often appraised the BPP's actions through the r 970 . A second wave of participant accounts also emerged in this period which offered a more personal interpretation of the BPP's decline. A third period emerged in the early 2000 s that abandoned the obsession with Pearson's study and focussed instead on the BPP's contribution to African American and American culture beyond its political program and violent image. The article reveals the paradox at the heart of the local approach, one which recent studies addressed in their focus on the BPP's Oakland chapter and their return to a tight chronological approach that focussed on the BPP's peak years. It concludes by noting the remaining omissions in the BPP's historical record and anticipating further studies.

We want education that teaches us our true history and our role in the present-day society ${ }^{1}$

When Huey P. Newton and Bobby Seale sat down to write the Black Panther Party (BPP) platform and program they were most likely not concerned about provoking controversy within the ivory towers of the historical

Joe Street is Senior Lecturer in American History, Northumbria University.

The author wishes to thank Robert Cook, Simon Hall, Malcolm McLaughlin and the anonymous reviewer for $J A S$ for their helpful comments on this article.

${ }^{1}$ Bobby Seale and Huey P. Newton, "October I966 Black Panther Party Platform and Program," in Philip S. Foner, ed., The Black Panthers Speak (New York: HarperCollins, I970), 2. 


\section{Joe Street}

profession. Yet the "true history" of the BPP remains contested. Recent years have seen the publication of scores of articles, monographs, and memoirs. This may be seen by future historians as a golden age of Black Panther Studies and certainly will define the parameters of this subfield for many years to come. While historical writing on the BPP has reached maturity, the party itself remains contested ground and a subject of continuing historical debate. An evaluation of its historiography is timely, as the subfield enters its fourth decade. ${ }^{2}$

Initially, historians closely associated the BPP with civil rights history. Most general studies of the civil rights movement incorporate assessment of the BPP, largely focussing on the BPP's embodiment of Black Power sentiment and its violent image, relegating it to a cameo role within the morality play of the wider movement. Such studies imply that the BPP was an unfortunate reaction to the decline of the nonviolent movement, following in the footsteps of Malcolm X in offering an alternative model for black protest. ${ }^{3}$ While normally disagreeing with the suggestion that the BPP was little more than a howl of rage, many specialist studies of the BPP followed this teleological template, positioning the BPP at the end of the civil rights movement and at the core of Black Power. This "civil rights declension" theory was the dominant paradigm of early Panther studies.

Specialist Panther scholarship can be split into roughly three phases (naturally some works straddle phases). First is the participant-observer period, in which assessment of the party was dominated by the published works of former Panthers and contemporary witnesses. This phase focussed closely on the BPP's central triumvirate: Newton, Seale, and Eldridge Cleaver. This "great-black-men" history of the BPP suggested that the many

${ }^{2}$ David Garrow's robust review of six recent BPP studies is a useful primer for the omissions in the historical record. It is best read as a call for the construction of a thorough narrative history of the BPP, and includes a solid chronology of the Oakland chapter's history during its peak years. Garrow dismissed much BPP historiography, particularly that written before 1994, and de-emphasized the development of BPP philosophy, concentrating instead on the rise-and-fall narrative of the BPP's leadership and the tension between the leaders and the led. The limitations of the review structure militated against the inclusion of a thorough historiographical review but the bibliography - particularly its inclusion of newspaper reports and trial transcripts - is indispensable. David Garrow, "Picking up the Books: The New Historiography of the Black Panther Party," Reviews in American History, 35 (2007), 650-70.

${ }^{3}$ See, for example, Robert Weisbrot, Freedom Bound: A History of America's Civil Rights Movement (New York: Penguin, 1990), 236-37; Robert Cook, Sweet Land of Liberty? The African-American Struggle for Civil Rights in the Twentieth Century (Harlow: Longman, I 998), 25I-52 (which stresses the role of the FBI in plotting the BPP's downfall); Adam Fairclough, Better Day Coming: Blacks and Equality, 1890-2000 (New York: Penguin, 200I), 316-19. 
ordinary members and fellow travelers were incidental to the party's history. The BPP's narrative is dominated by major set pieces: Newton and Seale writing the Ten Point Platform and Program in October I 966; the May I 967 invasion of the California State Capitol; the manslaughter of Officer John Frey some five months later and Newton's subsequent trial, incarceration, and release; and the assassinations of Bobby Hutton (April i 968), of Alprentice "Bunchy" Carter and John Huggins (January i 969), and of Mark Clark and Fred Hampton (December 1969). These normative accounts presented the BPP at the vanguard of late 1960 s radicalism and as an organization hounded by the Oakland police and the FBI. As was the case with early histories of the civil rights movement, they were largely characterized by "emotional commitment and righteous indignation," although some observers expressed skepticism about the BPP's modus operandi. ${ }^{4}$

The second phase followed the I994 publication of Hugh Pearson's hugely controversial account of Newton's life, The Shadow of the Panther: Huey Newton and the Price of Black Power in America. While Pearson's approach broadly reflected that of first-phase works, placing the BPP within the civil rights context and positioning Newton at the center of the BPP's narrative, his analysis of Newton's many failings suggested that the BPP's history was Newton's writ large. Moreover, Pearson's pathologizing of Newton's personality traits was implicitly extended to the BPP membership. In the following fifteen years numerous scholars turned their attention to rebutting Pearson's allegations and reclaiming a so-called balanced view of the BPP - one which emphasized its social programs, such as the Free Breakfast Program. These Pearson-era studies turned to the ordinary members of the BPP to offer an alternative narrative. This included a large number of local studies of BPP chapters. Taken together, these works might be termed "empiricist-activist" studies of the BPP, since they limited themselves to straightforward analysis of the BPP's activism, placing particular emphasis on participants' recollections of their own involvement. Eschewing interpretative approaches which might place the BPP in wider contexts, these studies focussed on what the Panthers did and how they did it.

A third phase has recently emerged, one which might be termed the postPearson era. Here, scholars moved beyond the obsession with Pearson's work to seek out new approaches to the BPP. These accounts referred either explicitly or implicitly to the BPP's continuing and contested place in African American and American popular culture to indicate that the BPP's political

${ }^{4}$ Dan Carter quoted in Charles W. Eagles, "Towards New Histories of the Civil Rights Era," Journal of Southern History, 66 (2000), 8 I 8. 


\section{Joe Street}

campaign was perhaps not the party's most enduring legacy. They suggest that we move beyond examination of the BPP's political protest if we are to comprehend the BPP's meaning and significance for American history. As importantly, they highlight the potential of BPP historiography to influence wider trends in American history, particularly in terms of class protest, the white flight to the suburbs, and the tension between local and national narratives of African American protest.

\section{THE PARTICIPANT-OBSERVER PERIOD}

David Garrow recently lamented that BPP historiography "begins from a surprisingly weak and modest foundation." Primary materials for the early years of the BPP are largely restricted to the pages of The Black Panther Party Black Community News Service and contemporary press reports. The BPP, quite simply, was not prone to creating, storing, and maintaining a paper record of its activities. ${ }^{\mathbf{6}}$ Consequently, the most visible and articulate Panthers - Newton and Seale in particular - were able to dominate early writing on the organization. Four themes united their writings: first, an overwhelming focus on BPP leaders; second, a fawning attitude towards Newton; third, a related tendency to mythologize the BPP; fourth, a heavy focus on police brutality. Seale's Seize the Time cemented Newton as a character of legend; its breathless account of the BPP's early days - derived from a series of conversations between Seale and Cleaver and replete with late i 960 argot - draws the reader into close identification with its subject and has for some become fact. ${ }^{7}$ Newton's Revolutionary Suicide largely echoed Seale's narrative and was a self-conscious attempt to demonstrate Newton's intellectual credentials, one which was bolstered by the publication of

5 Garrow, 650.

${ }^{6}$ Even a brief examination of the Dr. Huey P. Newton Foundation Records (Manuscripts Department, Stanford University) reveals the paucity of material dating from the ig6os, with the vast majority of material deriving from I97 I onwards. David Garrow noted the existence of numerous court cases involving BPP members, which supplement the archival material. Garrow, 665, n. 7; 667, nn. I 8, 21 .

7 Jane Rhodes, Framing the Panthers: The Spectacular Rise of a Black Power Icon (New York: New Press, 2007), 234-35; Robert Scheer, ed., Eldridge Cleaver: Post-Prison Writings and Speeches (New York: Random House, I 969), I 56 ; Bobby Seale, Seize the Time: The Story of the Black Panther Party (London: Arrow, 1970), 46, 107, 213 (note chapter headings such as "We Hit the Streets," "Huey Backs the Pigs Down," "Huey Digs Bob Dylan"). In contrast, A Lonely Rage, Seale's autobiography, focussed on Seale's pre-BPP life, only introducing Newton at the halfway point and glossing over much of the BPP's history in favour of graphic descriptions of Seale's sexual encounters and the details of the Chicago and New Haven trials. Bobby Seale, A Lonely Rage (New York: Bantam, i 978). 
In Search of Common Ground. A collection of transcripts from Newton's I97I conversations and seminars with the psychoanalyst Erik Erikson, In Search abandoned Seale's concept of Newton the man of action. ${ }^{8}$ To Die for the People, the Toni Morrison-edited collection of Newton's most significant writings, was less pretentious, and more accurately traced the development of his thought. Yet with J. Herman Blake's recent claim that he, and not Newton, wrote many of the articles that appeared in this collection, it will surely receive more rigorous analysis. ${ }^{\mathbf{9}}$ Blake's assertion potentially casts a great shadow over Newton's contribution to African American intellectual history. Newton's Ph.D. thesis, "War against the Panthers," should come under similar scrutiny. This one-sided account predictably relied on Newton's belief that an FBI-led conspiracy worked to destroy the BPP. ${ }^{10}$

A series of contemporary journalistic accounts appeared alongside these works. Gene Marine's and Reginald Major's leadership-focussed accounts largely echoed Seale's interpretation of the BPP. ${ }^{11}$ Ruth-Marion Baruch and Pirkle Jones's The Vanguard, a photographic essay on the BPP, cemented one of the most powerful and enduring legacies of the BPP: its arresting visual appearance. ${ }^{12}$ A number of writers cast a more skeptical eye over the party, and particularly over its leadership cadre, whilst presenting ordinary members as victims of white oppression rather than as active

${ }^{8}$ Erik H. Erikson and Huey P. Newton, In Search of Common Ground: Conversations with Erik H. Erikson and Huey P. Newton (New York: Dell, I 973), 2 I-30.

9 Roz Payne, "WACing off: Gossip, Sex, Race, and Politics in the World of FBI Special Case Agent William A. Cohendet," in Jama Lazerow and Yohuru Williams, eds., In Search of the Black Panther Party: New Perspectives on a Revolutionary Movement (Durham: Duke University Press, 2006), i 80, n. 22.

10 The dissertation was published as Huey P. Newton, War against The Panthers: A Study of Repression in America (New York: Harlem River Press, 1996). Cleaver's contributions add little to knowledge of the BPP's inner workings. Soul on Ice was written prior to induction, and its successor, Cleaver's 1978 memoir Soul on Fire, was an extended mea culpa, written after Cleaver's recantation of his Panther past. The collection of post-prison writings and speeches contains little on the party itself, and Lee Lockwood's conversation is similarly polemical. Eldridge Cleaver, Soul on Ice: Selected Essays (London: Jonathan Cape, I 969); idem, Soul on Fire (Waco, TX: Word Books, 1978); Scheer; Lee Lockwood, Conversation with Eldridge Cleaver (New York: Delta, I 970).

11 Reginald Major, The Panther Is a Black Cat: An Account of the Early Years of the Black Panther Party - Its Origins, Its Goals, and Its Struggle for Survival (Baltimore: Black Classic Press, 2007 rpt.); Gene Marine, The Black Panthers (New York: Signet, 1969).

12 Ruth-Marion Baruch and Pirkle Jones, The Vanguard: A Photographic Essay on the Black Panthers (Boston: Beacon, I 970). See also Stephen Shames, The Black Panthers (New York: Aperture, 2006); Howard Bingham, The Black Panthers (Los Angeles: Ammo Books, 2008); Mario Van Peebles, Ula Y. Taylor, and J. Tarika Lewis, Panther: A Pictorial History of the Black Panthers and the Story bebind the Film (New York: Newmarket Press, 1995). 


\section{Joe Street}

individuals. ${ }^{13}$ In highlighting the intellectual vacuum at the heart of the BPP, these observers anticipated later critical interpretations of the organization. Don Schanche's The Panther Paradox concluded that the party's members - "naïve, malleable ghetto kids" - were insane and less intelligent than the average Boy Scout. ${ }^{14}$ Earl Anthony's participant-observer account suggested that, while Schanche's view of the rank and file was cruel, his understanding of the central cadre's vacuity was not unfair. An FBI informant who was expelled from the BPP in 1969, Anthony presented the party as a paramilitary organization led by opportunists rather than visionaries. ${ }^{15}$ Tom Wolfe's cheeky i 970 New York article coined the phrase "radical chic."16 Where he suggested that the BPP was a vacuous and opportunist group, another "new journalist" went further. Gail Sheehy's condemnatory report on the party in New Haven, Connecticut focussed almost exclusively on the murder of supposed FBI informant Alex Rackley. Troublingly, Sheehy did not follow the court case that resulted from Rackley's murder to its conclusion, leaving her readers unaware that the jury's decision rebutted her accusations. Her conclusion, however, was rather prescient: "[if] the Black Panther Party, or its successor, decides to survive at all costs, it may have to copy the Mafia technique." ${ }^{\text {"17 }}$ Building on these accounts, Michael Newton's Bitter Grain highlighted the national presence of the BPP but focussed overwhelmingly on the California Panthers' frequent clashes with

${ }^{13}$ Look for Me in the Whirlwind: The Collective Autobiography of the New York $2 I$ (New York: Vintage, 1971) shared the tales of the New York Panthers charged with plotting to bomb buildings in New York City and assassinate various police officers. Marine was not immune to the leadership-centered focus: ordinary members first appeared within 50 pages of the book's end; Bobby Hutton, the BPP's first recruit, was mentioned only in the context of his death. Marine, I 37-39 (Hutton), i 82 (other members).

14 Don Schanche, The Panther Paradox: A Liberal's Dilemma (New York: Van Rees Press, I 970), ix, xi, 226. Gilbert Moore, A Special Rage (New York: Harper and Row, I97I), used the Newton trial to reexamine the author's own politics and by extension those of the black community.

15 Seale, Seize, 309; Earl Anthony, Picking up the Gun: A Report on the Black Panthers (New York: Dial, 1970).

16 Tom Wolfe, "Radical Chic: That Party at Lenny's," New York, 8 June i 970, available at http://nymag.com/news/features/46170 (accessed I9 May 2008), republished in idem, Radical Chic and Mau-Maning the Flak Catchers (New York: Farrar, Straus and Giroux, 1970).

17 Gail Sheehy, Panthermania: The Clash of Black against Black in One American City (New York: Harper \& Row, I 97 I), 8-9, I 2-2 I, I08-9, I I 5 ; Michael E. Staub, "Black Panthers, New Journalism, and the Rewriting of the Sixties," Representations 57 (Winter 1997), 62-63. The murder of Alex Rackley has led to further studies, most notably Donald Freed, Agony in New Haven: The Trial of Bobby Seale, Ericka Huggins, and the Black Panther Party (New York: Simon and Schuster, I973); and the forensic Paul Bass and Douglas W. Rae, Murder in the Model City: The Black Panthers, Yale, and the Redemption of a Killer (New York: Basic Books, 2006), which adds a necessary coda. 
the police - not a great surprise given that Newton also writes "true crime" books. ${ }^{18}$ This Oakland-centered approach to the BPP dominated writing on the organization until the i 990 .

Meanwhile, academic studies offered friendlier interpretations of the BPP. John Courtwright noted that as the party matured between May I 970 and April I97I, violent rhetoric in The Black Panther declined sharply, findings that were confirmed by Charles Hopkins. ${ }^{19}$ Carolyn Calloway argued that external enemies engendered group cohesion within the BPP. Calloway also identified Panther Minister for Culture Emory Douglas's art as a key element of the BPP's modus operandi, an analysis that was not followed up for some twenty years. ${ }^{20}$ Offering more concrete evidence than Earl Anthony's suspect account, Kenneth O'Reilly's Racial Matters revealed the extent of FBI monitoring of the BPP, and was supplemented by Ward Churchill and James Vander Wall's partisan Agents of Repression. For the latter, FBI disinformation was central to the BPP's internal schisms and its feud with the rival US organization. $^{21}$ Charles Jones also picked up on this theme, placing considerable emphasis on legal, political and violent repression of the party, and pinpointing I 28 incidents of such governmental activities between I 966 and I97I. This "systematic" repression of the BPP, he argued, played "a pivotal role" in its collapse. ${ }^{22}$ Problematically, the latter two studies tended towards

${ }^{18}$ Michael Newton, Bitter Grain: Huey Newton and the Black Panther Party (Los Angeles: Holloway House, 1980; revised I991), II5-19, I23-93, 216; http://michaelnewton. homestead.com (accessed 20 August 2008).

19 John A. Courtwright, "Rhetoric of the Gun: An Analysis of the Rhetorical Modifications of the Black Panther Party," Journal of Black Studies, 4 (1974), 249-67; Charles William Hopkins, "The Deradicalization of the Black Panther Party, 1967-1973" (University of North Carolina at Chapel Hill dissertation, 1979). Helen Stewart's I980 dissertation, "Buffering: The Leadership Style of Huey P. Newton, Co-founder of the Black Panther Party" (Brandeis University PhD dissertation, 1980) is another friendly study, based on flimsy evidence.

${ }^{20}$ Carolyn R. Calloway, "Group Cohesiveness in the Black Panther Party," Journal of Black. Studies, 8 (1977), 55-74. Another early study traces the BPP's relationship with Jean Genet through the latter's 1970 sojourn in the United States. Robert Sandarg, "Jean Genet and the Black Panther Party," Journal of Black Studies, r6, 3 (March 1986), 269-82.

${ }^{21}$ Kenneth O'Reilly, "Racial Matters": The FBI's Secret War on Black America, 1960-1972 (New York: Free Press, I989), 293-324, 329-31 ; Ward Churchill and Jim Vander Wall, Agents of Repression: The FBI's Secret War against the Black. Panther Party and the American Indian Movement (Boston: South End Press, I990, corrected edition), 40-44, 52-53, 63-99. The feud with US remains controversial; the best account thus far is Scot Brown, Fighting for US: Maulana Karenga, the US Organization, and Black. Cultural Nationalism (New York University Press, 2003).

${ }^{22}$ Charles E. Jones, "The Political Repression of the Black Panther Party, 1966-1971: The Case of the Oakland Bay Area," Journal of Black. Studies, I 8 (I988), 4I 5-34, 4I 6, 432, original emphasis. 


\section{Joe Street}

a conspiracy-theory approach to the BPP, which absolved individual Panthers of blame for their role in the party's downfall. This issue has become central to the historiographical debate swirling around the BPP. While it has elements of the chicken-and-egg argument, the revealing of FBI counterintelligence in these works has profoundly influenced our understanding of the BPP's demise. The publication of O'Reilly's study in particular enabled many Panther sympathizers and members to conclude that the level of FBI provocation explained - and to a certain extent justified - the BPP's actions.

The I990s was a period in which the i 960 seneration developed an increasing awareness of its role in history and became desirous that its contribution to the tumult of the ig6os was not lost. Numerous former protesters, including BPP members, turned to autobiography in order to tell their stories. ${ }^{23}$ Elaine Brown's and David Hilliard's contributions proved to be by parts honest and unrevealing. Despite the inevitable lack of candor on controversial events, their autobiographies offered valuable insights into the psychology of life in the BPP. ${ }^{24}$ Hilliard confirmed how the party gave ordinary black men a sense of purpose, but suggested that the BPP's political education classes succeeded only in teaching BPP members what to think, not how to think. Both he and Brown detailed the immense pressure of life in the BPP; where Hilliard took refuge in drugs, Brown fled the party. ${ }^{25}$ Both

${ }^{23}$ Ronald Grele, "A Second Reading of Experience: Memoirs of the i96os," Radical History Review, 44 (1989), I59-66; Kathryn L. Nasstrom, "Between Memory and History: Autobiographies of the Civil Rights Movement and the Writing of Civil Rights History," Journal of Southern History, 74 (2008), 325-64.

24 Note, for example, Brown's treatment of the Carter and Huggins assassination and the Kathleen Smith case. Elaine Brown, A Taste of Power: A Black Woman's Story (New York: Pantheon, 1992), I64-67, 383; David Hilliard, This Side of Glory: The Autobiography of David Hilliard and the Story of the Black Panther Party (Boston: Little, Brown, I 993), I 30-3 I, I 8 5-97, 204-5, 207-8.

${ }^{25}$ Hilliard, I 1 8, passim; E. Brown, 3-16. The success of both books acted as a form of redemption for both authors. In reconnecting with his old network of friends and comrades, Hilliard became a prime mover in the campaign to sanctify Newton, resulting in his appointment as executive director of the Dr. Huey P. Newton Foundation. Working alongside Newton's widow Fredrika, Hilliard became involved in further publishing enterprises and a campaign to maintain control over Newton's posthumous image. The Huey P. Newton Reader appeared in 2002, co-edited by Hilliard. Hilliard's introduction glossed over Newton's character flaws, presenting Newton as the BPP's theoretician and "the preeminent African-American leader for social justice in the world." David Hilliard, "Introduction," in David Hilliard and Donald Wiese, eds., The Huey P. Newton Reader (New York: Seven Stories Press, 2002), 17. The collection reprinted large portions of Revolutionary Suicide and To Die for the People and a shorter extract from War against the Panthers, supplemented by the transcript of a bizarre televised confrontation with William F. Buckley, and a series of short pieces written in the I970s that highlighted the increasing pretension of 
suggested that the pressure of being a leader, an image and an individual was similarly damaging for Huey Newton. Brown's Newton was a tortured soul, ground down by the expectations of his followers and desirous of a normal life that his psychology and notoriety rendered impossible. He took refuge in cocaine, cognac, and isolation, a weak man at the mercy of self-destructive instincts. ${ }^{26}$ Hilliard suggested that Newton envisaged the BPP as essentially a gang, and enjoyed the close personal bonds that developed in the early days. ${ }^{27}$ The party's expansion in the late i 960 s served only to impose further pressures on Newton that he responded to by surrounding himself with sycophants. ${ }^{28}$ Equally, he shrugged off the responsibilities that came with fame by escaping his own consciousness through heavy drug use. Yet this drug addiction was also tragic, since it stripped him of his Panther identity. Meanwhile the black community that the BPP had once galvanized experienced a similar descent. In Hillard's account, Newton's decline is a metaphor for the community: it had once been proud, politically active, and protective of its members, but the influx of drugs had transformed it into a crimeridden and violent hyper-capitalist society. ${ }^{29}$ Despite their obvious affection for their former leader, both Hilliard and Brown implicitly agreed with the BPP critics. While they remained sure that the BPP had idealistic aims, they understood that the party - and Newton in particular - was also prone to iniquity and violence, characteristics that featured strongly in the critical journalistic accounts of the first phase of BPP studies.

Newton's writing. Hilliard also edited a curious facsimile collection of extracts from The Black Panther which focussed heavily on the r 970 s and included numerous incomplete articles. He also presented an accompanying hagiographical DVD documentary. After a successful book tour, Brown too became an important gatekeeper to the memory of the BPP. See http://www.blackpanther.org/foundation.htm and http://www.blackpanther. org/index.html (both accessed 20 August 2008); Kate Coleman, "The Last Panther," FrontPageMagazine.com, July i 997, http://www.frontpagemag.com/articles/Read.aspx? GUID=AiB8 2823-I9I4-488A-8A30-BoDA2467I4EE (accessed 20 August 2008); rehashed in Kate Coleman, “A Black Panther's Last Hurrah,” Salon.com, March 2000, http:// archive.salon.com/news/feature/2000/03/06/hilliard/index.html (accessed 20 August 2008); David Hilliard, ed., The Black Panther Intercommunal News Service, 1967-1980 (New York: Atria, 2007); Curtis K. Austin, Up against The Wall: Violence in the Making and Unmaking of the Black Panther Party (Fayetteville: University of Arkansas Press, 2006), 423-26; http:// www.elainebrown.org/index.htm (accessed i 2 Nov. 2008).

${ }^{26}$ E. Brown, 239-40, 271-72, 282, $285,438-39$.

27 These bonds were so close that they became almost sexual: not long after his installation in an Oakland penthouse, Newton invited Hilliard to join him and an unnamed woman in a three-way sexual encounter. Hilliard, This Side of Glory, 3 I 4.

${ }^{28}$ Hilliard, This Side of Glory, I I 7, I I 8, I 79, I 80, 25 2, 295, 307, 3 I ०-1 I , 3 I 2, 3 1 8, 332, 337, 340, $353,363-65,369-73$.

29 Hilliard, This Side of Glory, I I, 407-8, 384, 394-40 I, 41 5-1 7, $425-26$. 


\section{THE TWO HUGHS}

Hugh Pearson took the ambivalence encoded in the Hilliard and Brown autobiographies far further, producing the single most controversial and important study of the BPP, The Shadow of the Panther. Building on the critical observers' accounts, Pearson unambiguously sided with the second half of Frantz Fanon's dictum that "each generation must ... fulfil it [s historical mission], or betray it." ${ }^{\text {30 }}$ His portrait of the party incensed Panther sympathizers and reignited interest in the BPP's history to such an extent that it is impossible to consider subsequent Panther scholarship without understanding it. Indeed, perhaps its most significant consequence was the emergence of a series of local studies that challenged Pearson's focus on Newton and the Oakland BPP, taking issue with both his interpretation of and approach to the BPP's history.

While Pearson was no right-winger, his analysis of Newton and the BPP owed much to an antagonistic approach to the BPP of a number of rightof-center writers, notably David Horowitz. ${ }^{31}$ A close friend of a number of Panthers including Newton, Horowitz cut his ties with the left following the murder of his friend, the bookkeeper Betty Van Patter, by Panther operatives. Soon after, he provided research material to the journalist Kate Coleman, whose 1978 article "The Party's Over" revealed the depths to which the BPP, and Newton in particular, had sunk. ${ }^{32}$ Horowitz himself concluded that the BPP was no more than a gang of hoodlums and hustlers. Less an analysis of the party than a character assassination of Newton, his

${ }^{30}$ Frantz Fanon, The Wretched of the Earth (Harmondsworth: Penguin, 1967), I66.

${ }^{31}$ David T. Beito, "Hugh Pearson R. I. P.," History News Network, 3 Sept. 2005, http:// hnn.us/blogs/entries/ I I $54 . h$ tml (accessed 4 Sept. 2008); Richard Prince, "Author, Columnist Hugh Pearson Found Dead at 47," 2 Sept. 2005, http://www.maynardije.org/ columns/dickprince/050902_prince (accessed 4 Sept. 2008).

32 Kate Coleman and Paul Avery, "The Party's Over," New Times, ro July 1978, reprinted in David Wier and Dan Noyes, Raising Hell: How the Center for Investigative Reporting Gets the Story (Reading MA: Addison-Wesley, 1983), 223-60; Peter Collier and David Horowitz, Destructive Generation: Second Thoughts About the '6os (New York: Free Press, 1989), I60, 320-2 I. See also Kate Coleman, "A Death In Berkeley," Heterodoxy, 3, 3 (March/April I995), I, 4-9. Now available at http://www.discoverthenetworks.org/Articles/march_ april_95\% $\%{ }_{51} \% 5$ D.pdf (accessed 20 May 2008). Coleman attacked David Hilliard for his willingness to use his history and the legacy of the BPP for his own financial gain. She also took exception to the approach of a group of academic researchers whose work examined the BPP. Coleman, "The Last Panther"; idem, "A Black Panther's Last Hurrah"; idem, "The Panthers for Real," FrontPageMagazine.com, June 2003, http://www.frontpagemag. $\mathrm{com} /$ Articles/Printable.aspx?GUID $={ }_{7} \mathrm{~B}_{2} \mathrm{C}_{3} 899-\mathrm{BDB}_{2}-427 \mathrm{I}-9602-827$ I $\mathrm{A}_{5} \mathrm{C}_{1} \mathrm{EC}_{92}$ (accessed I9 August 2008). 
account of the BPP's nefarious underbelly helped to lay further foundations for Pearson's work. ${ }^{33}$

Pearson initially felt affinity for Newton through their shared first name. As his research deepened, however, this bond disappeared, and part of the book's animus must be attributed to Pearson's disillusionment at Newton's shortcomings. ${ }^{34}$ His evaluation of Newton's criminal side was detailed and devastating. Pearson's Newton was little more than a street thug who, through a combination of luck, willpower, and opportunism, found himself at the vanguard of the African American political struggle. Using the BPP as a cover for criminal activities, Newton became addicted to fame and notoriety. This was a man partially defined by an unreconciled duality of criminality and intellectualism. ${ }^{35}$ Newton's paranoia, short temper and addiction to excitement frequently overwhelmed his considerable intellect, capacity for reasoning, and eventually his life. Intoxicated first by confrontation and revolution, Newton replaced the somatic high these actions gave him with an artificial high derived from cognac, cocaine, and, later, crack. His demise at the hands of the violent street culture that he had emerged from and helped to define was, for Pearson, inevitable, but also tragic: "I'm tapped out, guys," Newton apparently lamented in the early i980s, "I have no more energy. I just want to get high." This portrayal of Newton will prove Pearson's most enduring contribution to BPP studies. ${ }^{36}$

33 Collier and Horowitz, I4 1 -65. See also David Horowitz, "Black Murder Inc.," Heterodoxy, I, Io (March I993), I, I I-I 5 . Available at http://www.discoverthenetworks.org/Articles/ 1 $993 \% 20 \mathrm{March} \% 20 \mathrm{Vol} \% 20 \mathrm{I}, \% 20 \mathrm{No}$.pdf (accessed 20 May 2008). Horowitz has since continued his sniping through the Internet, largely confined to the pages of the selfedited Front Page Magazine. David Horowitz, "Who Killed Betty Van Patter," Salon, I 3 Dec. I 999, http://archive.salon.com/news/col/horo/I999/I2/I3/betty/index.html; www. frontpagemag.com (both accessed 20 May 2008).

${ }^{34}$ Hugh Pearson, The Shadow of the Panther: Huey Newton and the Price of Black. Power in America (Reading, MA: Addison-Wesley I994), 342, 347; Prince. See also Hugh Pearson, "Writing about Black Panthers and Black People," Heterodoxy, 2, Io (Sept. 1994), 4-6, which revealed that Landon Williams, one of Pearson's most useful sources, was so disgusted at the book that he distanced himself from it upon its publication. Now available at http://www. discoverthenetworks.org/Articles/1994\%20September\%20Vol\%202\%20No2.pdf (accessed 20 May 2008). See also interview with Pearson at Booknotes (2 I Aug. I 994), http:// www.booknotes.org/Transcript/?ProgramID $=_{1} 2$ I 3 (accessed 30 May 2008).

35 Pearson, Shadow, 234.

${ }^{36}$ Pearson, Shadow, 296, 3 I 3-1 4, 347. Peniel Joseph's authoritative history of the Black Power era, for example, included an assessment of Newton that is not terribly distant from Pearson's: "His personal transformation ... would prove to be lurching, unfinished, and often painful." Peniel E. Joseph, Waiting 'til The Midnight Hour: A Narrative History of Black Power in America (New York: Henry Holt, 2006), 208. 
Yet Pearson's account remains problematic. His willingness to rely on a small sample of oral histories - and the implications of such a stance - was documented by Errol Henderson. ${ }^{37}$ He included relatively little detail on events in Newton's life: the Frey murder trial, for example, was dispensed with in less than three pages. Pearson offered no sustained examination of Newton's psychology, and particularly of the impact of the Frey manslaughter and its aftermath. This constituted both the making of Newton the myth and the breaking of Newton the man, and an exploration of its implications would have added much to our understanding of him. ${ }^{38}$ Furthermore, while Pearson frequently referred to Newton's impressive intellectual feats, including his books and his academic success, he included no systematic evaluation of their meaning or authorship. This lack of interest in Newton's intellectual life is extended to the party. The central narrative of Pearson's BPP was its criminalization; Pearson's extension of Sheehy's Mafia suggestion added further ignominy to the BPP's tale. Moreover, in placing the BPP at the end of the civil rights movement, Pearson ensured that the organization remained the evil younger brother of the civil rights movement, the party's contribution limited to armed patrolling in Oakland and criminal activity.

Despite these limitations, Shadow of the Panther remains important. Nobody, for example, has convincingly rebutted Pearson's claims regarding the violence that BPP members meted out, or Newton's use of BPP funds to maintain a lavish lifestyle following his 1970 release from prison. ${ }^{39}$ For Pearson, there always was a permeable line between the BPP's political agenda and its criminality, one that demands serious consideration. His understanding that the $\mathrm{BPP}$ - and Newton in particular-brought what might be termed a "street" mentality to African American protest in Oakland certainly suggests that the BPP can be interpreted as a bridging organization between grassroots political protest and gang culture. ${ }^{40}$ In this, Pearson anticipated studies such as Gerald Horne's The Fire This Time, which in part linked the Los Angeles BPP to the city's African American gangs. Further study of this aspect of the BPP's history and legacy is needed. This will lead to greater understanding of the BPP's implications for black masculinity, a subtext of much writing on the BPP. ${ }^{41}$

37 Pearson, Shadow, 343-46; Errol Anthony Henderson, "Shadow of a Clue," in Kathleen Cleaver and George Katsiaficas, eds., Liberation, Imagination, and the Black Panther Party (New York: Routledge, 2001), I 97-207. Note the lurid details in Pearson's account of Seale's expulsion: Pearson, Shadow, 264.

39 See, for example, Henderson, 203.

38 Pearson, Shadow, I68, 220-2 I.

40 Ibid., i 18, i $92,202$.

41 Gerald Horne, Fire This Time: The Watts Uprising and the 1960s (New York: Da Capo, I997; first published 1995). For masculinity see, for example, Regina Jennings, "Poetry of the 


\section{THE PEARSON ERA}

Pearson's account proved to be the catalyst for a new phase of BPP studies, not least because it lay bare the amorality of a I 960 sicon. Given the central position of the BPP in the popular memory and history of the ig6os, his book was likely to be read widely; given its relentlessly negative tone, it was sure to provoke a vociferous response from Panther supporters. In focussing so heavily on Newton - and extrapolating Newton's flaws to the BPP at large - Pearson denied the transformative power of membership for ordinary members, which for many sympathizers and members was the party's most important legacy. Pearson's leadership-centered approach was also out of step with civil rights historiography, which had moved towards local studies of grassroots activism in the South. Thus numerous historians turned to the experience of ordinary BPP members, and often those outside the Bay Area, to rebut Pearson's claims and establish a grassroots history of the BPP, thus offering a more complex interpretation of African American workingclass activism in the post-civil rights era.

Shadow of the Panther's most obvious effect on BPP scholarship was the publication of two friendly biographies of Newton. Judson Jeffries's Huey $P$. Newton: The Radical Theorist was profoundly influenced by Erik Erikson's insistence that we treat Newton as an intellectual first and an activist second. ${ }^{42}$ After acknowledging that Pearson's account was "mostly accurate," Jeffries argued that Newton was a visionary intellectual whose thought deserves comparison with that of Du Bois, Hobbes, Locke, Bakunin, Rousseau, and Marx. ${ }^{43}$ His belief that Newton's concept of intercommunalism (essentially a transnational version of socialism) "represents a higher level of revolutionary consciousness" was taken almost verbatim from Newton's work. ${ }^{44}$ Jeffries revealed the simplicity that lay beneath Newton's obfuscatory jargon, and rejected any notion that others were involved in writing Newton's works, before offering a dubious conclusion on Newton's character: "That he had killed a white police officer [John Frey] proved how bad he was; at the

Black Panther Party: Metaphors of Militancy,” Journal of Black Studies, 29, I (Sept. I 998), Io6-29, which suggested that even female Panthers were prone to adopting male personas when writing of their experience in the BPP; Steve Estes, I Am a Man: Race, Manhood and the Civil Rights Movement (Chapel Hill: University of North Carolina Press, 2005), I 53-77, which explored the contradictions and struggles over gender within the BPP; Michele Wallace, Black Macho and the Myth of the Superwoman, 2nd edn (London: Verso, I 990).

42 The title was borrowed from one of Erikson's comments at the Yale seminar. Erikson and Newton, In Search of Common Ground, 43.

43 Judson L. Jeffries, Huey P. Newton: The Radical Theorist (Jackson: University Press of Mississippi, 2002), xvii, 42-47, 49, 50-5 I, 56, 59-61, 77, 82, I 20, I 3 I-32.

44 Ibid., 78 , I64, n. 55. 
same time, that he had not meant to kill the police officer proved how good he was. "45 Huey, David Hilliard, Keith Zimmerman, and Kent Zimmerman's attempt to rescue Newton the activist, also glossed over Newton's unsavory characteristics and returned to the mythology of Bobby Seale's account, reflecting both Hilliard's desire to rehabilitate his friend and the aims of the Dr. Huey P. Newton Foundation. ${ }^{\mathbf{4 6}}$ Where Hilliard's memoir was painfully candid, Huey was frustratingly vague. Uninterested in Newton's pre- and postBPP life, Huey included nothing on his intellectual achievements beyond a cursory mention of his PhD. Yet it is not without value - the account of Newton's escape to Cuba via Mexico in 1974 should form the basis of a more thorough examination. ${ }^{\mathbf{4 7}}$

More significantly, The Shadow of the Panther provoked numerous reassessments of the BPP. As if inspired by Point Four of the BPP Platform and Program, this response was unequivocally critical of Pearson: he failed to offer the "true" account of the BPP; his book did not have "balance." 48 This new phase in Panther studies was defined by two collections: Charles E. Jones's The Black Panther Party Reconsidered and Kathleen Cleaver and George Katsiaficas's Liberation, Imagination, and the Black Panther Party. Both publications included contributions of variable quality from academics, students, and former party members. For Jones, Panther scholarship was distorted, dismissive, inaccurate or incapable of analyzing the BPP's post-I 97 I history, with the reliance on autobiographical and journalistic accounts partially explaining such problems. The preponderance of local studies that focussed on a single, sensational event also skewed the historiographical record, and the lack of evaluation of the rank and file served ill those Panthers who did not become media figures. ${ }^{49}$ His collection went some way to redressing the imbalance. It confirmed the centrality of eyewitness accounts to BPP historiography, but more importantly added nuance to our understanding of the BPP's decline. Chris Booker emphasized the BPP's recruitment of the lumpen proletariat and failure to reform its criminal element; Winston GradyWillis placed emphasis on the state repression that Booker argued was in part a consequence of the BPP's "lumpenization." For Ollie Johnson, the

45 Ibid., I06-7, I I I, I44-45.

${ }^{46}$ See http://www.blackpanther.org/speakers.htm; http://www.blackpanther.org/ foundation.htm (accessed 9 Sept. 2008).

47 David Hilliard with Keith and Kent Zimmerman, Huey: Spirit of the Panther (New York: Thunder's Mouth Press, 2006), 75-108, 2 I 2-45, 247-49, 262.

48 Seale and Newton, "October I 966 Black Panther Party Platform and Program"; Pearson, Shadow rear cover.

49 Charles E. Jones, "Reconsidering Panther History: The Untold Story," in idem, ed., The Black Panther Party: Reconsidered (Baltimore: Black Classic Press, I 998), 7-I I. 
concentration of power among the BPP's central cadre, and specifically Newton's authoritarian control of the party, was the fundamental reason for the BPP's demise, a conclusion that is of great importance. ${ }^{\mathbf{5 0}}$ Yet with the exception of Nikhil Pal Singh's evaluation of BPP philosophy, elsewhere Reconsidered did not move beyond an interpretation of the BPP that celebrated its political and social activism. ${ }^{\mathbf{5 1}}$

Where the Jones collection placed equal emphasis on internal and external explanations for the BPP's demise, the Cleaver and Katsiaficas collection stressed the "carefully orchestrated disintegration of the Panthers" by US authorities, and elevated the personal experience of Panthers and fellow travelers over captious academic research. ${ }^{\mathbf{5 2}}$ The collection's dominant interpretation was embodied in Ward Churchill's updated analysis of the FBI's BPP COINTELPRO. Identifying twenty-nine Panthers killed by the police between I968 and I97I, including a number killed by other Panthers in the BPP's factional wars, Churchill concluded that negative assessments of the BPP should be "interrogated, challenged and discarded ... To excavate the understandings embodied in the party's programmatic successes, no matter how abbreviated the interval in which these were evident, is to reclaim the potentials that attended them. ${ }^{\mathbf{5 3}}$ While Erica Doss excerpted her groundbreaking I 998 article examining Emory Douglas's Revolutionary Art, most studies again

50 All the following references from Jones, Reconsidered. Former Panthers: Steve D. McCutchen, "Selections from a Panther Diary," i I 5-33; Miriam Ma'at-Ka-Re Monges, " "I Got a Right to the Tree of Life': Afrocentric Reflections of a Former Community Worker," I 36-45; Charles E. Jones, “'Talkin' the Talk and Walkin' the Walk': An Interview with Panther Jimmy Slater," I 47-53; Kathleen Cleaver, "Back to Africa: The Evolution of the International Section of the Black Panther Party (1969-1972)," 2 I I-54. Womanist studies: Monges; Cleaver; Tracye Matthews, "No One Ever Asks, What a Man's Role in the Revolution Is': Gender and the Politics of the Black Panther Party, 1966-1971," 276-304; Angela D. LeBlanc-Ernest, "'The Most Qualified Person to Handle the Job': Black Panther Party Women, I 966-1982," 305-34. Studies of the demise: Chris Booker, "Lumpenization: A Critical Error of the Black Panther Party," 337-62; Winston A. Grady-Willis, "The Black Panther Party: State Repression and Political Prisoners," $363-89$; Ollie A. Johnson III, "Explaining the Demise of the Black Panther Party: The Role of Internal Factors," 39I-4I4.

51 Nikhil Pal Singh, "The Black Panthers and the 'Undeveloped Country' of the Left," in Jones, Reconsidered, 57-105. See also Cleaver, "Back to Africa," 21 4-16.

${ }^{52}$ George Katsiaficas, "Introduction," in Cleaver and Katsiaficas, Liberation, xii. A number of the book's articles previously appeared in a special edition of New Political Science, 2 I, 2 (1999). The articles are those by Cleaver ("Women, Power and Revolution"); Clemons and Jones; Dahlerus and Davenport; and Doss, Reitan, and Umoja.

53 Ward Churchill, “'To Disrupt, Discredit and Destroy': The FBI's Secret War against the Black Panther Party," in Cleaver and Katsiaficas, ı09, i 6 (emphasis added). Churchill's article extended the introductory chapters in Churchill and Vander Wall, Agents of Repression. 
focussed on the BPP's activism and many attacked Pearson either implicitly or, in the case of Errol Henderson, explicitly. ${ }^{\mathbf{5 4}}$

Two major branches of Panther studies followed in the wake of these collections. The abundance of personal testimony in the collections and the I 995 reprint of Philip Foner's collection of articles from The Black Panther, which included numerous contributions from rank-and-file Panthers, plus the success of the Hilliard and Brown memoirs, prompted a number of Panthers to publish their own experiences. ${ }^{\mathbf{5 5}}$ This second wave of participant-observer accounts emphasized the personal cost of involvement with the BPP's rank and file. Just as David Hilliard and Elaine Brown used their autobiographies to explore the lifelong consequences of their relationship with Newton, these accounts emphasized how the BPP molded the subsequent lives of their authors. Significantly, the impact of the BPP was not necessarily positive. Earl Anthony's second memoir reevaluated his life, cataloguing the traumas that followed his expulsion from the BPP. Flores Forbes, one of Newton's bodyguards, detailed the personal impact of the BPP's increasing criminality. Assata Shakur, whose arrest following a shootout with police in New Jersey led to incarceration and a subsequent escape to Cuba, similarly revealed the physical and psychological consequences of a youth devoted to the party. The fugitive life offered Shakur and Forbes time for reflection and, in Forbes's case, redemption. ${ }^{\mathbf{5 6}}$ This

${ }^{54}$ Henderson, "Shadow of a Clue"; Erika Doss, "Revolutionary Art is a Tool for Liberation': Emory Douglas and Protest Aesthetics at the Black Panther," in Cleaver and Katsiaficas, 175-87; idem, "Imaging the Panthers: Representing Black Power and Masculinity, I960s-1990s," Prospects, 23 (1998), 483-5 16. The analysis of Douglas's art was deepened in Joe Street, The Culture War in the Civil Rights Movement (Gainesville: University Press of Florida, 2007), I 44-60, which positioned revolutionary art as a central feature of the BPP's philosophy. Douglas's art is now attracting worldwide attention. Sam Durant, ed., Black Panther: The Revolutionary Art of Emory Douglas (New York: Rizzoli, 2007) offers a representative selection.

55 Philip S. Foner, ed., The Black Panthers Speak, rpt (New York: Da Capo, 1995). Brown's book was selected as a notable book of the year in the New York. Times "Notable Books of the Year," I 993 . See http://query.nytimes.com/gst/fullpage.html?res= ${ }_{9} \mathrm{FoCEFD}_{71} \mathrm{I}_{3} 8 \mathrm{~F}_{93} 6 \mathrm{~A}_{3575} \mathrm{IC}_{1} \mathrm{~A}_{96} 6958260 \& \mathrm{sec}=$ \&spon $=$ \&pagewanted $=$ all (accessed 2 I Aug. 2008). Hilliard's received a respectable review in the New York Times. Adam Hochschild, "His Life as a Panther," 3 I Jan. I993, http://query.nytimes.com/gst/ fullpage.html?res $={ }_{9} \mathrm{FoCE}_{2} \mathrm{DA}_{10}{ }_{3} \mathrm{DFF}_{93}{ }_{2} \mathrm{~A}_{0} 75_{2} \mathrm{CoA}_{96} 6958260$ (accessed 2 I Aug. 2008).

56 Earl Anthony, Spitting in the Wind: The True Story bebind the Violent Legacy of the Black. Panther Party (Malibu, CA: Roundtable, 1990); Flores Forbes, Will You Die With Me? My Life and the Black Panther Party (New York: Atria, 2006); Assata Shakur, Assata: My Story (Chicago: Lawrence Hill, 1997). Shakur's account was first published in 1987 , but its themes place it as a reconciliation narrative. See also William Lee Brent, Long Time Gone: A Black Panther's True Life Story of His Hijacking and Twenty-Five Years in Cuba (Bloomington, IN: Universe, 2000); Jack Olsen, Last Man Standing: The Tragedy and Triumph of Geronimo Pratt 
redemption process was aided by a number of BPP reunions, where former comrades came together to reminisce and heal old wounds. ${ }^{\mathbf{5 7}}$

Gene Marine perceptively noted that, by mid-I968, "the story of the Black Panther Party fragments. From here on, there is no Panther story; there are only Panther stories, most of them local, and no one can keep up with them all." 58 The other branch of post-Pearson Panther studies to emerge ironically so, given Charles Jones's comments - focussed on these local stories. Pearson prompted academics to reveal the independence of grassroots Panther activity, thus rebutting his suggestion that the BPP was an Oakland organization with satellite chapters that simply followed orders from the national leadership. This phase of BPP studies also reflected a slightly earlier trend in the historiography of the civil rights movement. William Chafe's Civilities and Civil Rights (1980), a study of the development of African American protest in postwar Greensboro, North Carolina, initiated a period that was dominated by state-level studies of grassroots civil rights activism. Challenging the "Montgomery-to-Memphis" teleology that placed the public life of Martin Luther King Jr. as the focal point of the movement, these studies expanded the chronology of the movement beyond the I 95 5-68 limits imposed by a King-centered teleology. They revealed that the major civil rights organizations relied on networks of local activists that had worked for decades to establish organizing structures that could sustain a broader protest movement. Moreover, these histories argued persuasively that local activists - who often acted without the authority or knowledge of the movement's national leaders - were vital to the success of the struggle against Jim Crow; without them, King would never have become a national figurehead. ${ }^{59}$ A similar process can be discerned in the development of Panther studies: again, Pearson's focus on Newton came under attack.

(New York: Doubleday, 2000); Mumia Abu-Jamal, We Want Freedom: A Life in the Black Panther Party (Boston: South End Press, 2004), which combined reminiscences with Abu-Jamal's academic study of the party; Steve McCutchen, We Were Free for a While: Back to Back in the Black Panther Party (Frederick, MD: Publish America, 2008).

57 Regina Jennings, "The 35th Anniversary of the Black Panther Party," Seeingblack.com, 24 May 2002, http://seeingblack.com/xo52402/panthers35.shtml (accessed 9 Sept. 2008); Christopher Hooton, "Black Panthers Reunite for 4oth Anniversary," Laney Tower, i9 Oct. 1996, http://media.www.laneytower.com/media/storage/paperioo8/news/2006/10/19/ Features/Black.Panthers.Reunite.For.4oth.Anniversary-2379395.shtml (accessed 9 Sept. 2008); "The Black Panther Party at 40," http://www.jetcityorange.com/ BlackPanther4othReunion/ (accessed 20 Nov. 2008); various reunion meetings are documented at http://www.itsabouttimebpp.com/Reunions/reunions_index.html (accessed 9 Sept. 2008).

58 Marine, The Black Panthers, I94.

59 William H. Chafe, Civilities and Civil Rights: Greensboro, North Carolina, and the Black Struggle for Freedom (New York: Oxford University Press, I980); Eagles, “Towards New Histories," 
Local histories of the BPP broadly followed the "civil rights" template, placing the BPP at the tail end of the nonviolent movement and linking it with local civil rights activism. Challenging many of Gail Sheehy's conclusions, Yohuru Williams placed the New Haven BPP firmly within the context of urban black politics, presenting the chapter as a community organization that operated independently of the BPP's central leadership. In a similar fashion, Jon Rice positioned the Chicago BPP as an outgrowth of previous civil rights organizations in the city. ${ }^{60}$ Reynaldo Anderson and Robyn Spencer asserted that the transformative effect of the BPP on its membership constituted its most profound legacy. For Anderson, the experience of the Des Moines chapter suggested that pressures emanating from Oakland severely hindered local organizing initiatives. ${ }^{61}$ Judson Jeffries's Comrades collection added the tales of the Baltimore, Winston-Salem, Cleveland, Indianapolis, Milwaukee, Philadelphia, and Los Angeles chapters. Notably, most chapters had a membership that could be counted in the dozens. Largely ignoring the intellectual life of the party, Comrades placed the BPP firmly in an activist context, stressing the importance of the social programs and the nefarious activities of the local police, leading the collection to be more suggestive of a Benign Panther Party. Few contributions investigated the criminal element of the BPP, and regrettably the article on the Los Angeles BPP ignored its relationship with US, which is perhaps the most significant aspect of the local chapter's history. ${ }^{62}$

827-29. For a broad collection of articles (including two on the BPP) that takes direct influence from John Dittmer's Local People: The Struggle for Civil Rights in Mississippi (Urbana: University of Illinois Press, 1994), the classic local study, see Jeanne Theoharis and Komozi Woodard, eds., Groundwork: Local Black Freedom Movements in America (New York: New York University Press, 2005).

60 Note that Williams branded George Sams, a BPP member who was heavily implicated in the Rackley murder, an FBI informant, relying on circumstantial evidence. Sams - who was not interviewed by Williams - claims that he was not an informer. Yohuru Williams, Black Politics/White Power: Civil Rights, Black Power, and the Black Panthers in New Haven (St. James, NY: Brandywine Press, 2000), I40, I63; Garrow, "Picking up the Books," 667, n. I 8; Bass and Rae, Murder in the Model City, 262-63; Jon Rice, "The World of the Illinois Panthers," in Jeanne F. Theoharis and Komozi Woodard, Freedom North: Black Freedom Struggles Outside the South, 1940-1980 (New York: Palgrave, 2003), 4I-64.

${ }^{61}$ Reynaldo Anderson, "Practical Internationalists: The Story of the Des Moines, Iowa, Black Panther Party," in Theoharis and Woodard, 282-99, esp. 291-94; Robyn Ceanne Spencer, "Inside the Panther Revolution: The Black Freedom Movement and the Black Panther Party in Oakland, California," in ibid., 300-17 (which offered no evaluation of the Oakland BPP's seedier side).

${ }^{62}$ Judson L. Jeffries, ed., Comrades: A Local History of the Black Panther Party (Bloomington: Indiana University Press, 2007); Judson L. Jeffries and Malcolm Foley (Jeffries's MA student), "To Live and Die in LA," in ibid., $255-90$. The authors of the latter article argued unconvincingly $(290, \mathrm{n} .72)$ that that the BPP's history in the city should be treated 
Two local studies - both of the party in Oakland - moved beyond this template, however, and suggested possibilities for reintegrating the history of the BPP with other themes in American history. Daniel Crowe placed the $\mathrm{BPP}$ in a greater longitudinal context, arguing that we should move beyond the simplistic notion that it emerged from the civil rights movement, the "sixties," and the anticolonial struggle. Instead, it should be associated more closely with the problems of the Bay Area's inner cities, as revealed by the direct link between Bobby Seale's War on Poverty work and the foundation of the BPP. ${ }^{63}$ Robert Self noted that the BPP viewed black Oakland as "an exploited colony ... controlled from the suburban perimeter," thus placing the BPP's anticolonial rhetoric within the context of suburbanization. More importantly, he argued that the BPP is best understood through examination of white suburbia's expansion, the related economic and social decline of biracial inner cities, and the failure of moderate civil rights organizations to develop strong bases in working-class communities. The BPP's selfimposed isolation from these groups - a consequence of their interest in economic development and black middle-class advancement - hindered its progress as it turned away from revolution in the r 970 . Self did not merely position the BPP within the activist context. Instead, the BPP was placed in a much richer intellectual context, one that encompassed radical internationalism, Garveyism, the "socialist laborite culture of Oakland's waterfront unions," and the self-defense traditions embodied by Malcolm X; the party's history is therefore not beholden to the civil rights declension thesis. American Babylon's nuanced interpretation of BPP philosophy and understanding of the party's relationship with broader intellectual and political trends anticipated a new era of Panther studies. It posed deep questions concerning the BPP's position in African American and white American history - notably suggesting that it was the last political snarl of the urban

separately from that of US but did not even touch on the interorganizational relations, for which Brown, Fighting for US, should be consulted. Of the nine contributors to the volume, three were graduate students at Purdue University during Jeffries's period of employment there, two more (excluding Jeffries) studied or worked at Ohio State University, Jeffries's current employers. Elsewhere Jeffries concluded that local newspaper coverage of the BPP varied from city to city. Judson L. Jeffries, "Local News Coverage of the Black Panther Party: An Analysis of the Baltimore, Cleveland, and New Orleans Press," Journal of African American Studies 7, 4 (2004), 19-38. A further collection, Yohuru Williams and Jama Lazerow, eds., Liberated Territory: Untold Local Perspectives on the Black Panther Party (Durham: Duke University Press, 2008), was published too late for consideration in this article.

${ }^{63}$ Daniel E. Crowe, Prophets of Rage: The Black Freedom Struggle in San Francisco, 1945-1960 (New York: Routledge, 2000), 5, 8, 223-27. 
proletariat as suburbanization took whites (and their tax dollars) away from the cities. ${ }^{64}$

\section{THE POST-EMPIRICIST ERA}

The latest wave of Panther studies moved away from the activist interpretations and from Pearson's work to turn to the cultural meaning of the $\mathrm{BPP}$ as it receded into history. Jeffrey Ogbar, for example, placed the BPP at the center of the Black Power movement. Strongest on the BPP's understanding of the role of the lumpen proletariat and on the party's internal struggles with gender and sexual equality, Ogbar assessed the BPP's contribution to the development of African American identity. The significance of Ogbar's work was not in the positioning of the BPP within the wider Black Power movement but in its signaling of a new interpretative framework for study of the party. Eschewing the traditional approach, Ogbar examined the inner workings of the party and its contribution to African American culture, particularly in terms of its empowering rhetoric and actions. Here the setpiece events in the BPP's history took a secondary role to the meaning and symbolism of the BPP for the black American population. ${ }^{65}$

In Search of the Black Panther Party confirmed the beginning of a new era in BPP studies. Its editors agreed with Ogbar, arguing that we should look to Panther culture to understand the party. ${ }^{\mathbf{6 6}}$ Hence the collection examined

${ }^{64}$ Robert O. Self, American Babylon: Race and the Struggle for Postwar Oakland (Princeton: Princeton University Press, 2003), I, 228. The issue of public space was made more explicit in James A. Tyner, "Defend the Ghetto': Space and the Urban Politics of the Black Panther Party," Annals of the Association of American Geographers, 96, I (2006), 105-1 8. Tyner analyzed the BPP's protest in terms of its questioning of the relationship between social justice and urban public spaces, posing the question who owned the streets? While wisely placing the BPP within a black nationalist (as opposed to civil rights) context, Tyner ignored the BPP's violent underbelly and the lack of private space within the BPP.

65 Jeffrey O. G. Ogbar, Black Power: Radical Politics and African American Identity (Baltimore: Johns Hopkins University Press, 2004), 69-1 22. For Peniel Joseph, another historian keen to position the BPP within the tradition of black radicalism most closely associated with Black Power, tension between the BPP leaders was central to the Party's decline. Joseph, Waiting 'til The Midnight Hour, 205-26, 228-38, 24I-54, 26I-71, 286-88.

${ }^{66}$ Jama Lazerow and Yohuru Williams, "Introduction: The Black Panthers and Historical Scholarship: Why Now?", in idem, In Search of the Black Panther Party, I-1 2. Other examples of the wider approach to BPP history include Craig Peck's and Daniel Perlstein's investigations of BPP educational practice and Regina Jennings's analysis of BPP poetry. Craig Peck, "Educate to Liberate: The Black Panther Party and Political Eduation" (Stanford University PhD dissertation, 200I); Daniel Perlstein, "Minds Stayed on Freedom: Politics and Pedagogy in the African-American Freedom Struggle," American Educational Research Journal, 39 (Summer 2002), 249-77; Jennings, "Poetry of the Black Panther Party," I06-29. 
Revolutionary Art, the role of white liberal guilt in the BPP's relationship with other radical organizations, and the influence of the BPP on Latino radicalism, and returned to the BPP-FBI relationship, this time from a more interesting angle. Roz Payne suggested that scholars have misjudged the actions of the FBI. She challenged one of the major assumptions concerning the FBI-BPP relationship: her primary resource, William Cohendet, a San Francisco-based FBI agent, stated that the local office had not one serious or reliable BPP informant. Whether Cohendet himself is reliable remains moot. ${ }^{67}$ An examination of the life of mixed-race Massachusetts Panther Frank "Parky" Grace is similarly thought-provoking, uncovering numerous underexplored aspects of Panther history: the "porous boundary" between criminal and political activity and the impact of racial identity, military service, and further education on individual Panthers. Finally, Edward Morgan studied the media's presentation of the BPP. Less interested in the irony that the BPP courted the media in an attempt to boost its profile, Morgan concluded that the media's simplistic representation of the BPP was a great hindrance to the party. His conclusions pointed towards the work conducted by Jane Rhodes on the very same subject. ${ }^{68}$

Rhodes's Framing the Panthers argued that a major theme of the BPP's history was the tension between its efforts to obtain media attention and the media's attempt to channel the BPP story into traditional narratives of black male violence and criminality. The BPP needed publicity to attract donations as bail charges and legal fees were gradually strangling the party's finances in the late ig6os. Unfortunately, press reports tended to focus overwhelmingly on the BPP's violence, trapping the BPP within its own rhetoric. Yet Rhodes ultimately argued that the media were not completely successful in destroying the BPP's reputation. Postliminary representations, including Mario Van Peebles's 1995 movie Panther and Roger Guenveur Smith's electrifying one-man theatrical play A Huey P. Newton Story, offered a more rounded

67 Tim Lake, "The Arm(ing) of the Vanguard, Signify(ing), and Performing the Revolution: The Black Panther Party and Pedagogical Strategies for Interpreting a Revolutionary Life"; Joel Wilson, "Invisible Cages: Racialized Politics and the Alliance between the Panthers and the Peace and Freedom Party"; David Barber, "Leading the Vanguard: White New Leftists School the Panthers on Black Revolution"; Jeffrey O. G. Ogbar, "Brown Power to Brown People: Radical Ethnic Nationalism, the Black Panthers, and Latino Radicalism, 1967-1973"; Roz Payne, "WACing off: Gossip, Sex, Race, and Politics in the World of FBI Special Case Agent William A. Cohendet," all in Lazerow and Williams, In Search of the Black Panther Party, respectively 306-23, I9I-222, $223-5$ I, 25 2-86, I $58-80$.

68 Jama Lazerow, "'A Rebel All His Life': The Unexpected Story of Frank 'Parky' Grace”; Edward Morgan, "Media Culture and the Public Memory of the Black Panther Party," both in Lazerow and Williams, In Search of the Black Panther Party, respectively at 104-57 (quote on I34), 324-73. 
appreciation of the BPP's legacy than contemporary media. Nevertheless, the negative portrayal of the Panthers in Forrest Gump - in which Panthers were depicted as hypocritical, ideological misogynists - suggests that mainstream American culture remained convinced that the BPP was little more than a gaggle of violent black males. ${ }^{69}$

This violence, both real and rhetorical, "constituted the central element driving the group's decision-making processes," according to Curtis Austin, author of another signal volume in recent BPP studies, Up against the Wall: Violence in the Making and Unmaking of the Black Panther Party. De-emphasizing the psychological and historical roots of this decision, Austin offered a wealth of evidence to reveal how the BPP's leaders attempted to justify the role of violence and how central it was to BPP praxis. A synthesis of topdown and bottom-up histories of the BPP, Up against the Wall indicated how the behavior of the central cadre influenced ordinary members. It argued that clandestine and illegal operations were not unusual in the BPP's daily work, concluding that "violence was seen as a kind of glue that held things intact." ${ }^{\text {"70 }}$ Although clearly sympathetic towards the BPP, Austin's dismissal of the social and community programs - awarded less than twenty of over three hundred pages - was a damning critique of their importance. One major question arises from Austin's study, however, and it revolves around Pearson's interpretation of the BPP. Was the BPP little more than a gang of violent thugs?

Rhodes and Austin revealed perhaps the most important tension within BPP studies as it entered its fifth decade. Both focussed almost exclusively on the I966-7 I period, suggesting that as the BPP moved from revolution to reform in the early i970s it lost both momentum and relevance. Both

69 Rhodes also argued that this media relationship was a prime factor in the rise of Eldridge Cleaver. Where most accounts focused on internal factors that enabled Cleaver to supplant Newton during the early months of the latter's incarceration, Rhodes argued that Cleaver - the most articulate and media-savvy Panther - was able to reach out to a relatively wealthy white liberal constituency. Rhodes, Framing the Panthers, 201; Panther (Polygram film, I995, director: Mario Van Peebles); A Huey P. Newton Story (40 Acres and a Mule film, 200I, writer and performer: Roger Guenveur Smith, director: Spike Lee) based on Smith's one-man play; Forrest Gump (Paramount film, i 994, director: Robert Zemeckis). Notably, the audible lyrics of the song playing on the Gump soundtrack during the BPP scene (Jimi Hendrix's version of "Hey Joe") are: "where you going with that gun in your hand." Another fruitful area for Rhodes to study might have been the PBS documentary series Eyes on the Prize. The two episodes that feature the BPP ("Power!" and "A Nation of Law" - chapters nine and twelve) focused almost exclusively on the issue of police brutality and the BPP's militant, gun-toting protest image, with a small section on the social programs - somewhat unsurprisingly, since the chronology and approach of the series placed the BPP firmly in a context of civil rights activism.

70 Austin, Up against The Wall, xxi, 335. 
authors asserted the BPP's national importance during the earlier period, when its membership peaked and it was at its most paramilitary. Rhodes revealed how the BPP invaded the homes of ordinary white Americans during a period of major political and cultural upheaval. For Austin, the presence of BPP chapters throughout the nation was suggestive of the organization's importance in black America. ${ }^{71}$ The danger with such a narrow chronological focus, however, is that it ignores the development of the BPP into a social reform organization, locking the party into a mediadefined image of berets, guns, and stern rhetoric. Benefiting from the larger amount of archival material from the I970s Oakland BPP, longitudinal studies theoretically enable greater understanding of the BPP's development throughout its sixteen-year history, and should encourage deeper engagement with the development of the organization's philosophy. Yet such studies have tended to gloss over the fact that by the mid-r97os the BPP involved dozens rather than thousands of activists. They have struggled to come to terms with the fact that the BPP's most important contributions to American politics, society, and culture had passed by 1972. Furthermore, since so few chapters remained after Newton's 1972 call for Panthers to congregate in Oakland and focus on electoral politics, longitudinal study of the BPP implies that we should see the organization primarily as a Bay Area social reform group. The BPP's brief period of international notoriety thus becomes a by-product of its ability to attract media attention, the late ig6os vogue for radical chic, and perhaps residual interest in the civil rights movement. If we are to appreciate the BPP over its entire life, then we should accept that it was little more than a local organization. More importantly, as Bobby Seale's candidacy for mayor suggests, the mere appellation "Black Panther" was a severe impediment to success in the I970s. One must therefore question the importance of chapters outside the Bay Area, particularly those with a small membership. The question that then emerges is whether the historical focus is a result of the name "Black Panther Party" alone, rather than of the achievements of the chapters. This returns to Austin's and Rhodes's suggestion that the central cadre - and the media attention that it attracted - is most worthy of the historian's attention.

Even though the tide is turning away from empirical studies of the BPP, gaps remain in our knowledge. The BPP's involvement in Oakland's political process in the r97os demands further investigation, using the archival

${ }^{71}$ Paul Alkebulan, Survival Pending Revolution: The History of the Black Panther Party (Tuscaloosa: University of Alabama Press, 2007), 58, for the relationship between the BPP's popularity and its militarism. Note also the titles of BPP leaders - field marshall, for example - for an indication of the BPP's paramilitary image. 


\section{Joe Street}

material in the Dr. Huey P. Newton Foundation records. More research is needed on Panther fellow travelers such as the National Committee to Combat Fascism. This group identified strongly with the BPP but was never officially incorporated into the organization. Friendly scholars have stressed the importance of the survival programs but we are still lacking a thorough qualitative and quantitative assessment of their effectiveness - how many children, for example, attended the Panther schools and how do they now reflect on their childhood experience? How many boxes of food were distributed to the poor, and how many were sourced legally? We also have no systematic analysis of BPP members - their backgrounds, roles in the party, and particularly the impact of the BPP on their later lives. Empirical study of these issues will round out our understanding of the party in its activist context. Unfortunately, it will never be able to construct a completely accurate account of the BPP's early days. With Newton's death and Hilliard's compromised position it is highly unlikely that Seale's account - which blurs the line between myth and history so effectively that it is difficult to separate the two - will be challenged. For example, we shall likely never unravel the relationship between the early BPP and the Revolutionary Action Movement, the Soul Students Advisory Committee, and the Afro-American Association. Elsewhere, nobody has followed the suggestion that the BPP had a relationship with urban gang culture. Given the centrality of gang membership to urban working-class African American masculinity in the subsequent two decades it might be fruitful to engage in a thorough assessment of the BPP's meaning for black masculinity. There has also been no evaluation of the impact of childhood experiences on BPP members. Newton, Seale, Hilliard, and Elaine Brown, amongst numerous other Panthers, were displaced as children. Was the BPP a search for "home"? Did the BPP offer a surrogate family for its members? Finally, it is likely that consensus will not be reached in the debate over the BPP's demise. Friendly scholars will always be able to point to the FBI's nefarious activities to explain the paranoia that overwhelmed the BPP in the late I960s. Recent oral histories with BPP members back up this argument but it remains dangerous to rely too heavily on such accounts. It is comforting for former Panthers to see the FBI as the primary reason for the BPP's collapse, since it absolves them of blame. Yet the studies that focus on internal factors are equally unsatisfactory, for the BPP members were not pathological and were working under extreme pressure for months and years at a time.

Beyond the empirical approach, historians will continue to ponder the wider meaning of the BPP, particularly its relationship with class politics in Oakland and black radical politics in the national and international spheres. 
While it would be foolish to divorce the BPP completely from the civil rights movement, future studies should look to these wider perspectives for further insights into the party's significance. More to the point, BPP studies will not remain ghettoized as a subfield of civil rights studies, but instead should influence wider trends in American history. Curtis Austin's reintegration of local and national narratives, for example, has numerous implications for the history of twentieth-century African American protest. ${ }^{72}$ Similarly, Robert Self's understanding of the connection between the BPP and suburbanization offers useful pointers to the redefinition of urban and African American history. While the "true history and role" of the BPP will remain unwritten, BPP studies such as these suggest that we are now in a position to comprehend the party's multifaceted contribution to American history.

${ }^{72}$ Like BPP studies, civil rights historiography has in part been defined by a split between local and national approaches. Recent local studies of the civil rights movement include Emilye Crosby, A Little Taste of Freedom: The Black Freedom Struggle in Claiborne County, Mississippi (Chapel Hill: University of North Carolina Press, 2005); Peter B. Levy, Civil War on Race Street: The Civil Rights Movement in Cambridge, Maryland (Gainesville: University Press of Florida, 2003). Studies with new approaches include Brian Ward, Just My Soul Responding: Rhythm and Blues, Black Consciousness and Race Relations (London: UCL Press, 1998); Brian Ward, ed., Media, Culture, and the Modern African American Freedom Struggle (Gainesville: University Press of Florida, 200I); Renee C. Romano and Leigh Radford, eds., The Civil Rights Movement in American Memory (Athens: University of Georgia Press, 2006). Suzanne E. Smith, Dancing in the Street: Motown and the Cultural Politics of Detroit (Cambridge, MA: Harvard University Press, 1999), arguably bridges the divide. One of the most fruitful branches of recent civil rights studies is the new approach to the movement's opponents; Roz Payne's study is the first example of a similar approach to the study of the BPP. Clive Webb, ed., Massive Resistance: Southern Opposition to the Second Reconstruction (New York: Oxford University Presss, 2005); Eagles, "Towards New Histories of the Civil Rights Era," 842-43; Payne, "WACing off." 